\title{
EPIDEMIOLOGIC FEATURES OF HIV INFECTION IN THREE MUNICIPALITIES OF INNER RIO DE JANEIRO STATE, BRAZIL
}

\begin{abstract}
SUMMARY
In Brazil relatively little attention is being paid to the study of the features of the spread of the AIDS epidemic towards small cities and rural areas. We report a descriptive study on the epidemiological features of HIV infection among 208 adult patients seen between July 1999 and May 2006 in the municipal HIV/AIDS Programs of three cities of inner Rio de Janeiro State: Saquarema, Santo Antonio de Pádua and Miracema. A portrait of a heterosexual epidemic emerged, with an overall male to female ratio of 1.1. More than $90 \%$ were residents of the studied cities, demonstrating a local demand for HIV-related assistance and the importance of municipal HIV/AIDS Programs. Past or current use of snorted cocaine was reported by a quarter of the patients. Older age and male gender were independent predictors of having a diagnosis of AIDS at presentation. The latter is in accordance with a more recent wave of epidemic spread towards female gender. A low frequency of male circumcision, an important determinant of heterosexual HIV transmission, was recorded. Almost $60 \%$ of the patients first presented in advanced stages of HIV infection, suggesting the existence of a large pool of undiagnosed cases in the community.
\end{abstract}

KEYWORDS: Acquired immunodeficiency syndrome; Brazil; Epidemiology; HIV-1 infection; Small municipalities.

\section{INTRODUCTION}

One of the major features of the current Brazilian AIDS epidemic is its spread towards small cities and the innermost parts of the country 6,7,12. Small Brazilian cities are being challenged to provide care to an increasing number of HIV-infected patients, yet they generally have a much less comprehensive health infrastructure to deal with the multidisciplinary aspects of HIV infection. In cities without an established municipal HIV/AIDS Program, patients need to be referred to receive care where facilities and expertise in the medical management of HIV infection is available. The true magnitude of the epidemic in small Brazilian cities and rural areas is unknown and there is an urgent need to perform studies on issues such as incidence and other epidemiologic characteristics, opportunities of interventions to halt epidemic spread, the spectrum of clinical complications, confidentiality issues, and the prevalence of resistance to antiretroviral drugs. Certainly, the AIDS epidemic in Brazil needs appropriately designed field studies that generate primary data.

Rio de Janeiro State is the third most populous and the second most heavily burdened by the epidemic in the country. As of December 2004 a cumulative number of 43,629 AIDS cases had been reported in Rio de Janeiro State since the beginning of the epidemic ${ }^{4}$. However, this figure may largely underestimate the true magnitude of the epidemic. It has been shown that $51.9 \%$ of all AIDS-related deaths in the State of Rio de Janeiro between 1991 and 1995 have not been reported to the Ministry of Health ${ }^{10}$.

Little is known about the epidemiologic features of HIV infection in relatively small Brazilian cities. A seminal ecological study found that among AIDS cases reported between 1993 and 1996 the male to female ratio (MTFR) was smaller in small cities (2.77) when compared to large urban centers $(3.44)^{12}$. We recently reported on the clinical and epidemiological features of HIV infection and AIDS among patients who received care between 1999 and 2003 in the municipal HIV/AIDS Program of the small municipality of Miracema, in northwestern Rio de Janeiro State ${ }^{6}$. We found an inverted MTFR, an absolute predominance of heterosexual transmission, a high frequency of previous use of snorted cocaine, and that more than half of the cohort first presented in advanced stages of immunodeficiency. A phylogenetic analysis of HIV-1 sequences recovered from this cohort was performed to better understand the routes of viral spread in a small Brazilian municipality ${ }^{7}$. We found multiple clusters of genetically related HIV1 strains, suggesting the existence of sexual networks and a high incidence phylogenetic profile.

We report herein the epidemiologic features of HIV infection in two additional cities of inner Rio de Janeiro State: Saquarema, a 


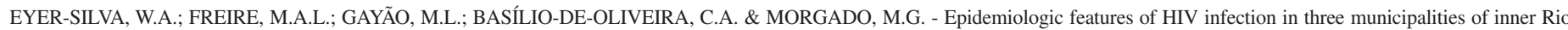
de Janeiro State, Brazil. Rev. Inst. Med. trop. S. Paulo, 49(5): 303-307, 2007.

nationwide famous municipality for its tourist attractions, and the northwestern Santo Antonio de Pádua, a small municipality located very close to Miracema. The study of the features of HIV infection and AIDS in these cities shall broaden our understanding of the characteristics of HIV infection and AIDS in inner cities of Rio de Janeiro State.

\section{METHODS}

Saquarema is situated $116 \mathrm{~km}$ north from the municipality of Rio de Janeiro, in the so called Sun Coast region (Fig. 1). Bathed by the Atlantic, the municipality enjoys a worthy reputation of being a place of outstanding natural beauty and attracts thousands of domestic and
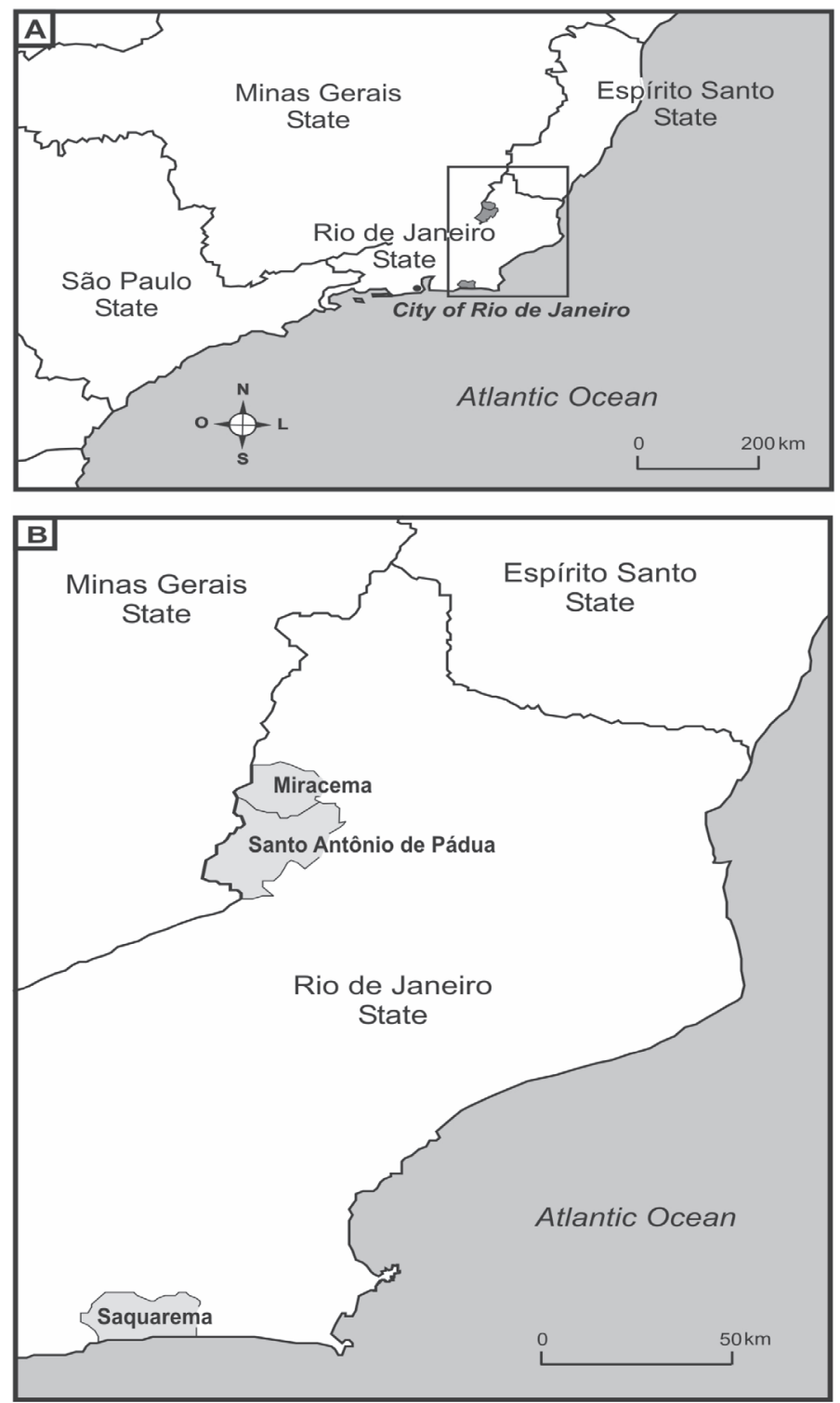

Fig. 1 - A) The Brazilian Southeast macroregion with its four component States; B) The cities of Saquarema, in the Sun Coast subregion, Miracema and Santo Antonio de Pádua, in the Northwestern subregion of Rio de Janeiro State, at the border of Minas Gerais. foreign visitors and vacationers every year. As of July 2005, the municipality counted 61,591 inhabitants distributed in a geographic area of $355 \mathrm{~km}^{2}$ (http://www.ibge.gov.br/cidadesat/). The municipal HIV/AIDS program of Saquarema was established in the year 2000. Santo Antonio de Pádua has an area of $612 \mathrm{~km}^{2}$ (including eight predominantly rural or semi-rural districts) and is situated in northwestern Rio de Janeiro State, $263 \mathrm{~km}$ far from the capital, at the border of Minas Gerais State (Fig. 1). A major economic activity of the municipality is the extraction and processing of decorative stones. As of July 2005, the municipality counted 42,078 inhabitants (http:// www.ibge.gov.br/cidadesat/). Until August 2001, HIV-infected patients were referred to receive care in the municipality of Itaperuna, which is $60 \mathrm{~km}$ apart. A municipal HIV/AIDS Program has now been established and patients benefit from regular medical appointments in the municipal hospital and local dispensation of drugs used in the management of HIV infection.

The features of adult HIV infection in these two cities were compared to those previously reported from Miracema, a detailed characterization of which is presented elsewhere ${ }^{6}$. For the purpose of the present study, data from the Miracema study was updated to include patients seen until May 2006. The study protocol was reviewed and approved by the Ethics Review Board at Instituto de Pesquisa Clínica Evandro Chagas, Fundação Oswaldo Cruz, Rio de Janeiro.

As of the year 2000, the cities of Saquarema, Santo Antonio de Pádua, and Miracema had been assigned by the "Instituto de Pesquisas Econômicas e Aplicadas" human development index values of 0.762 , 0.754 , and 0.733 , respectively. Among the 91 municipalities of Rio de Janeiro State, these figures correspond, respectively, to positions $45^{\text {th }}$, $50^{\text {th }}$, and $70^{\text {th (9) }}$.

After obtaining signed informed consent, clinical and epidemiological characteristics of all HIV-infected adult patients who received care in the municipal HIV/AIDS Programs of Saquarema and Santo Antonio de Pádua between October 2001 and May 2006 were collected on standardized questionnaires. The diagnosis of HIV infection was made based on the algorithm proposed by the Brazilian Ministry of Health ${ }^{2}$. Patients were staged according to the 1993 Classification System of the Centers for Disease Control and Prevention $^{3}$. Demographic, epidemiologic, social and behavioral variables, as well as the clinical stage of HIV infection were recorded as of first medical visit. We also assessed male circumcision status, an important determinant of HIV heterosexual transmission ${ }^{5}$, through either questioning or genital examination.

Differences between categorical and continuous variables were compared by applying the chi-square $\left(\chi^{2}\right)$ test for $k$ independent samples, the Fisher's exact test, and the Kruskal-Wallis rank sum test, where appropriate ${ }^{11}$. The null hypothesis was that the three cohorts were samples from the same or identical populations. A type I error was pre-specified as $<0.01$. When the null hypothesis was rejected, data was further explored by an analysis of residuals to understand better where in the $r \times k$ contingency table were the significant differences ${ }^{11}$. A multivariate logistic regression analysis was also used to identify variables independently associated with having an AIDSdefining CDC stage at presentation. Statistical analyses were performed using the software $\mathrm{R}$, version $2.2^{8}$. 


\section{RESULTS}

Between October 2001 and May 2006 a total of 93 and 34 adult patients received care in the municipal HIV/AIDS Programs of Saquarema and Santo Antonio de Pádua, respectively. The cumulative number of adult patients seen in the municipal HIV/AIDS Program of Miracema (between July 1999 and May 2006) was 81. Therefore, 208 patients were seen in these three cities. The MTFRs of HIV infection in these three cities were $1.6,1.0$, and 0.8 , respectively, whereas the
MTFR of cases fulfilling a diagnosis of AIDS (CDC stages A3, B3, and $\mathrm{C}$ ) at presentation was consistently higher: $3.5,1.3$, and 0.9 , respectively (Table 1 ).

The mean (SD [standard deviation]) age at presentation was 34.6 (SD 11.5), with an age range of 16-74 years. A total of 23 (11\%) patients were older than 50 years when diagnosed with HIV infection. More than $90 \%$ were inhabitants of the studied cities and around three-fourths attributed the acquisition of HIV infection to unprotected heterosexual

Table 1

Demographic, epidemiological, clinical, and behavioral data of 208 adult HIV-infected patients followed at the municipal HIV/AIDS Programs of Saquarema, Santo Antonio de Pádua, and Miracema, inner Rio de Janeiro State, July 1999 to May 2006

\begin{tabular}{|c|c|c|c|c|}
\hline & $\begin{array}{c}\text { Saquarema } \\
\text { Oct. } 01 \text { - May } 06 \\
(\mathrm{n}=93)\end{array}$ & $\begin{array}{c}\text { St }^{\circ} . \text { Ant. Pádua } \\
\text { Oct. } 01 \text { - May } 06 \\
\quad(\mathrm{n}=34)\end{array}$ & $\begin{array}{c}\text { Miracema } \\
\text { July } 99 \text { - May } 06 \\
(\mathrm{n}=81)\end{array}$ & $\begin{array}{c}\text { Total } \\
\text { July } 99 \text { - May } 06 \\
(\mathrm{n}=208)\end{array}$ \\
\hline Female gender $(\mathrm{n}, \%)$ & $35(37.6 \%)$ & $17(50 \%)$ & $44(54.3 \%)$ & $96(46.4 \%)$ \\
\hline Male to female ratio (HIV infection) & 1.6 & 1.0 & 0.8 & 1.1 \\
\hline Male to female ratio (AIDS cases) & 3.5 & 1.3 & 0.9 & 1.7 \\
\hline Age $($ mean $\pm \mathrm{SD})$ & $35.6 \pm 12.2$ & $36.8 \pm 11.2$ & $32.5 \pm 10.5$ & $34.6 \pm 11.5$ \\
\hline Age range (years) & $18-74$ & $23-58$ & $16-63$ & $16-74$ \\
\hline$\leq 20$ & $4(4.3 \%)$ & - & $5(6.2 \%)$ & $9(4.3 \%)$ \\
\hline $21-30$ & $31(33.3 \%)$ & $14(41.2 \%)$ & $37(45.6 \%)$ & $82(39.4 \%)$ \\
\hline $31-40$ & $32(34.4 \%)$ & $8(23.5 \%)$ & $23(28.4 \%)$ & $63(30.3 \%)$ \\
\hline $41-50$ & $15(16.1 \%)$ & $6(17.6 \%)$ & $10(12.3 \%)$ & $31(14.9 \%)$ \\
\hline$>50$ & $11(11.8 \%)$ & $6(17.6 \%)$ & $6(7.4 \%)$ & $23(11 \%)$ \\
\hline \multicolumn{5}{|l|}{ Marital status (n, \%) } \\
\hline Single & $43(46.2 \%)$ & $10(29.4 \%)$ & $56(69.1 \%)^{*}$ & $109(52.4 \%)$ \\
\hline Married/divorced/stable union/widowed & $50(53.7 \%)$ & $24(70.6 \%)$ & $25(30.8 \%)$ & $99(47.6 \%)$ \\
\hline \multicolumn{5}{|l|}{ Place of birth (n, \%) } \\
\hline Native to the studied municipality & $23(24.7 \%)$ & $18(52.9 \%)$ & $61(75.3 \%)$ & $102(49 \%)$ \\
\hline Neighboring municipality & $14(15 \%)$ & $9(26.4 \%)$ & $11(13.6 \%)$ & $34(16.3 \%)$ \\
\hline Other & $56(60.2 \%)^{*}$ & $7(20.6 \%)$ & $9(11.1 \%)$ & $72(34.6 \%)$ \\
\hline \multicolumn{5}{|l|}{ Place of residence $(\mathrm{n}, \%)$} \\
\hline Residence in the studied municipality & $86(92.4 \%)$ & $30(88.2 \%)$ & $73(90.1 \%)$ & $189(90.8 \%)$ \\
\hline Other & $7(7.5 \%)$ & $4(11.7 \%)$ & $8(9.9 \%)$ & $19(9.1 \%)$ \\
\hline \multicolumn{5}{|l|}{ Level of education (n, \%) } \\
\hline None & $8(8.6 \%)$ & $7(20.6 \%)$ & $10(12.3 \%)$ & $25(12 \%)$ \\
\hline$<8 \mathrm{yr}$ & $56(60.2 \%)$ & $21(61.7 \%)$ & $46(56.8 \%)$ & $123(59.1 \%)$ \\
\hline$\geq 8 \mathrm{yr}$ & $29(31.2 \%)$ & $6(17.6 \%)$ & $24(29.6 \%)$ & $59(28.3 \%)$ \\
\hline Not recorded & - & - & $1(1.2 \%)$ & $1(0.5 \%)$ \\
\hline \multicolumn{5}{|l|}{ Exposure category (n, \%) } \\
\hline Heterosexual & $69(74.2 \%)$ & $31(91.1 \%)$ & $58(71.6 \%)$ & $158(75.9 \%)$ \\
\hline Homo/bisexual & $20(21.5 \%)$ & $3(8.8 \%)$ & $17(21 \%)$ & $40(19.2 \%)$ \\
\hline Intravenous drug use & $4(4.3 \%)$ & - & $1(1.2 \%)$ & $5(2.4 \%)$ \\
\hline Not recorded & - & - & $5(6.2 \%)$ & $5(2.4 \%)$ \\
\hline \multicolumn{5}{|l|}{ CDC stage $(\mathrm{n}, \%)$} \\
\hline Non AIDS-defining & $39(41.9 \%)$ & $11(32.3 \%)$ & $34(42 \%)$ & $84(40.4 \%)$ \\
\hline AIDS-defining & $54(58 \%)$ & $23(67.6 \%)$ & $47(58 \%)$ & $124(59.6 \%)$ \\
\hline \multicolumn{5}{|l|}{ Inhaled cocaine use $(n, \%)$} \\
\hline Yes & $27(29 \%)$ & $4(11.7 \%)$ & $20(24.7 \%)$ & $51(24.5 \%)$ \\
\hline No & $66(71 \%)$ & $30(88.2 \%)$ & $54(66.6 \%)$ & $150(72.1 \%)$ \\
\hline Not recorded & - & - & $7(8.6 \%)$ & $7(3.3 \%)$ \\
\hline \multicolumn{5}{|l|}{ Begun follow-up elsewhere $(\mathrm{n}, \%)^{* *}$} \\
\hline Yes & $17(18.3 \%)^{*}$ & - & $4(4.9 \%)$ & $21(10.1 \%)$ \\
\hline
\end{tabular}

$* \mathrm{p}<0.01 ; *$ Before the establishment of the HIV/AIDS Program in Santo Antonio de Pádua, patients received care in the municipality of Itaperuna. 


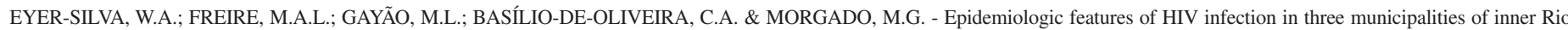
de Janeiro State, Brazil. Rev. Inst. Med. trop. S. Paulo, 49(5): 303-307, 2007.

intercourse. Isolated cases (five patients) of HIV infection attributed to the use of injected forms of cocaine were registered, whereas roughly one-fourth (51 patients) reported previous use of snorted cocaine. More than $70 \%$ had none or less than eight years of education. Only 11 $(5.3 \%)$ patients had partial or complete high-level education (data not shown). Nearly $60 \%$ of the patients had an AIDS-defining CDC stage when first presented for medical care (Table 1). We assessed male circumcision status in 99 patients. A total of 90 (90.9\%) were uncircumcised.

No statistically significant difference between the three groups was recorded when variables age, categorized age ranges, place of residence, level of education, exposure category, frequency of an AIDS-defining CDC stage at presentation, and previous use of snorted cocaine were studied. However, patients from Miracema were more likely to be single (as a marital status) and patients from Saquarema were more likely to have been born elsewhere and to have initiated HIV follow up in another municipality (Table 1). A multivariate logistic regression analysis was performed to identify variables independently associated with a diagnosis of an AIDS-defining CDC stage at presentation. We found that being a male patient (odds ratio $[\mathrm{OR}]=2.27 ; 95 \%$ confidence interval $[\mathrm{CI}]=1.67$ to $2.86 ; p=0.007$ ) and presenting at an older age (as a continuous variable, $\mathrm{OR}=1.06 ; 95 \% \mathrm{CI}=1.03$ to $1.09 ; p=$ 0.0004) were independent predictors of having a diagnosis of AIDS. The OR for increments of five and 10 years of age was found to be 1.37 and 1.89 , respectively.

\section{DISCUSSION}

A portrait of a heterosexual epidemic emerges from this study. The overall MTFR of cases of HIV infection was found to be 1.1, which means that $46.4 \%$ of all patients were of the female gender. The finding of higher MTFRs for cases who presented with a diagnosis of AIDS in the three studied cities, when compared to the MTFRs of HIV infection, is in accordance with a more recent wave of spread of the epidemic towards the female gender. In Miracema and Santo Antonio de Pádua, a female gender representation of half or more of the cohort was recorded, whereas in Saquarema more than $60 \%$ of the patients were male.

We found a few epidemiologic differences between the three studied cohorts. When compared to the two northwestern cities, patients from Saquarema were significantly more likely to have been born elsewhere and to have initiated HIV follow up in another municipality. In fact, Saquarema is a municipality that attracts people from all over Brazil. Also, the MTFR of HIV infection in Saquarema (1.6) was found to be higher than figures from the other two cities. In sharp contrast, most patients from Miracema and Santo Antonio de Pádua were receiving care in the municipality they were born and where MTFRs of HIV infection and AIDS were lower. Interestingly, patients from Miracema were more likely to be single (as a marital status) when compared to the other cities. The significance of this unexpected finding remains unknown. Although this may simply be explained by a somewhat younger cohort in Miracema (Table 1), differences in variable age among the three groups were not significant.

Nearly $60 \%$ of the patients first presented to medical attention in advanced stages of HIV-infection (Table 1), which suggests the existence of a large pool of undiagnosed cases in the community. This represents one of the most challenging facets of the spread of the epidemic towards relatively small Brazilian cities. Health care professionals in these areas are being faced with an increasing number of patients presenting with life-threatening HIV-related diseases. These patients need immediate diagnosis and prompt institution of appropriate treatment. Generally such patients are epidemiologically linked to other subjects who will also need HIV counseling and testing.

We found male gender and older age (as a continuous variable) to be independent predictors of a diagnosis of AIDS at presentation. Older age is plausibly associated with an AIDS diagnosis at presentation since profound CD4 cell count depletion and emergence of HIV-related disease usually ensues after many years of clinically silent, chronic asymptomatic infection. The association of male gender with AIDS at presentation also seems to be related to a more recent wave of HIV spread towards the female gender.

A common behavioral characteristic was a history of past or current use of snorted cocaine. Only isolated cases of HIV infection attributed to the use of intravenous drugs were recorded (five cases). In fact, in the State of Rio de Janeiro cocaine is more commonly used snorted than injected ${ }^{1}$. A history of alcohol abuse was also commonly reported by our patients (data not shown). The role of alcohol and non-injected forms of cocaine in unsafe sexual behavior and the spread of HIV in the State of Rio de Janeiro and other Brazilian regions where these problems are common still await appropriate investigations.

We assessed the frequency of male circumcision and found that more than $90 \%$ were uncircumcised. Although this figure by no means should be regarded as an estimate of the frequency of male circumcision in the overall population, it certainly suggests a low prevalence of male circumcision among residents of inner cities of the State. The uncircumcised status has been shown to be a major determinant of HIV transmission, mainly in African countries ${ }^{5}$. Studies on the prevalence of male circumcision in Brazil and on whether it is associated with viral spread among the heterosexual population are lacking.

We found that around $90 \%$ of the patients were residents of the studied cities, which demonstrates a local demand for HIV-related assistance. All efforts should thus be employed to the establishment of as many municipal HIV/AIDS Programs as possible, so that patients can benefit from state-of-the-art treatment in their own cities of residence. It is our opinion that such Programs are invaluable to provide local access to counseling, prevention (including vertical transmission prophylaxis), diagnosis, comprehensive case reporting, treatment, and may be of utmost importance to control epidemic spread. Health care professionals based in large urban centers may find it rewarding to share their knowledge and part of their time with small municipality professionals interested in the establishment of such Programs. Municipal authorities should realize the importance of offering logistic support and State health officials should be fully committed to provide efficient, low bureaucratic help. The role of community leaders, including those taking part in Municipal Health Councils, cannot be overemphasized.

In Brazil, AIDS is still considered a problem mainly restricted to 


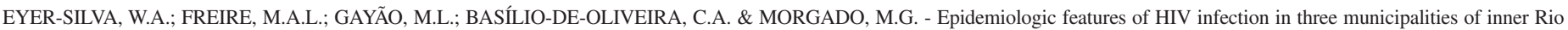
de Janeiro State, Brazil. Rev. Inst. Med. trop. S. Paulo, 49(5): 303-307, 2007.

large urban centers and relatively little attention is being paid to the study of the features of HIV infection in relatively small cities. Risk reduction campaigns should make it clear that HIV is finding a fertile field for dissemination among residents of small cities that engage in unprotected sexual intercourse. Such campaigns should not underestimate the importance of local press media, especially the comprehensive audience of local radio broadcasts in small cities and rural areas.

\section{RESUMO}

\section{Características epidemiológicas da infecção pelo HIV em três municípios do interior do Estado do Rio de Janeiro, Brasil}

No Brasil, relativamente pouca atenção vem sendo dispensada ao estudo das características do avanço da epidemia de Aids em direção aos pequenos municípios e áreas rurais. Apresentamos um estudo descritivo sobre as características epidemiológicas da infecção pelo HIV entre 208 pacientes adultos atendidos entre julho de 1999 e maio de 2006 pelos Programas Municipais de HIV/Aids de três municípios do interior do Estado do Rio de Janeiro: Saquarema, Santo Antonio de Pádua, e Miracema. Os resultados delineiam uma epidemia de perfil heterossexual, com uma razão de sexos homem-mulher de 1,1. Mais de $90 \%$ eram residentes das cidades estudadas, demonstrando uma demanda local por assistência relacionada ao HIV e a importância dos Programas Municipais de HIV/Aids. Um quarto dos pacientes referiu antecedentes de uso de cocaína inalada. Variáveis idade e gênero masculino mostraram-se independentemente associadas a um diagnóstico de Aids quando da apresentação. Esta última mostra-se de acordo com um mais recente avanço da epidemia em direção às mulheres. Registramos uma baixa freqüência de circuncisão masculina, um importante determinante da transmissão heterossexual do HIV. Quase $60 \%$ dos pacientes se apresentaram em estágios avançados de infecção HIV, o que sugere a existência de um grande reservatório de casos não diagnosticados na comunidade.

\section{ACKNOWLEDGEMENTS}

The authors are indebted to the patients, for agreeing to participate in this study, and to the many dedicated local health professionals in Miracema, Saquarema, and Santo Antonio de Pádua, without whom this study could not be possible.

\section{REFERENCES}

1. BASTOS, F.I.; STRATHDEE, S.A.; DERRIÇO, M. \& PINA, M.F. - Drug use and the spread of HIV/AIDS in South America and the Caribbean. Drugs: Education, Prevention and Policy, 6: 29-49, 1999.

2. BRASIL. MINISTÉRIO DA SAÚDE - Portaria número 59 de 28 de janeiro de 2003. Available at URL site: http://www.aids.gov.br/final/diagnostico/portaria.htm (accessed Feb 10th, 2007)

3. CDC - 1993 revised classification system for HIV infection and expanded surveillance case definition for AIDS among adolescents and adults. M.M.W.R. (RR-17), 41: 961-962, 1992.

4. ESTADO DO RIO DE JANEIRO - Boletim Epidemiológico DST \& AIDS. 2005.

5. EYER-SILVA, W.A. - A circuncisão masculina e a transmissão heterossexual do HIV. Rev. Saúde públ. (S. Paulo), 37: 678-686, 2003.

6. EYER-SILVA, W.A.; BASILIO-DE-OLIVEIRA, C.A. \& MORGADO, M.G. - HIV infection and AIDS in a small municipality in Southeast Brazil. Rev. Saúde públ. (S. Paulo), 39: 950-955, 2005.

7. EYER-SILVA, W.A. \& MORGADO, M.G. - Molecular epidemiology of HIV-1 infection in a small Brazilian county: usefulness of envelope and polymerase sequences to epidemiologic studies. J. acquir. immune. Defic. Syndr., 41: 664-670, 2006.

8. IHAKA, R. \& GENTLEMAN, R.R. - A language for data analysis and graphics. J. computat. graph. Statist., 5: 299-314, 1996.

9. IPEA. FUNDAÇÃO JOÃO PINHEIRO \& PNUD - Atlas do desenvolvimento humano no Brasil. Available at URL site: http://www.pnud.org.br/atlas/ (accessed Feb 10th, 2007)

10. LEMOS, K.R.V. \& VALENTE, J.G. - Death certificates as a marker for under-recording of AIDS cases. Cad. Saúde públ. (Rio de J.), 17: 617-626, 2001.

11. SIGEL, D.J. \& CASTELLAN, N.J. - Nonparametric statistics for the behavioral sciences. 2. ed. New York, McGraw-Hill, 1988

12. SZWARCWALD, C.L.; BASTOS, F.I.; ESTEVES, M.A. \& ANDRADE, C.L.T. - The spread of the AIDS epidemic in Brazil from 1987 to 1996: a spatial analysis. Cadern. Saúde públ. (Rio de J.), 16(suppl. 1): 7-19, 2000.

Received: 4 October 2006

Accepted: 20 April 2007 